\title{
In Vitro Evaluation of Apoptotic Induction of Butyric Acid Derivatives in Colorectal Carcinoma Cells
}

\author{
LIJI PATTAYIL and HARIKUMARAN-THAMPI BALAKRISHNAN-SARASWATHI \\ Department of Life Sciences, University of Calicut, Kerala, India
}

\begin{abstract}
Background/Aim: Butyric acid, a short chain fatty acid, plays an important role in the prevention of colon cancer. The aim of this study was to analyze the growth inhibitory and apoptotic effect of butyric acid derivatives in colorectal cancer cells. Materials and Methods: Human colorectal carcinoma HCT116 cells, were treated with the $I C_{50}$ concentration of sodium butyrate, indole-3-butyric acid, tributyrin and 2-aminon-butyric acid. Comet assay, caspase-3 assay and cell-cycle analysis were used to analyze apoptosis. Results: Tributyrin and indole-3-butyric acid showed the least $I C_{50}$ values at $24 \mathrm{~h}$ incubation. Butyric acid derivatives significantly activated caspase-3 activity compared with the control. Additionally, indole-3-butyric acid and tributyrin caused $G_{0} / G_{1}$ and $G_{2} / M$ phase arrest. Conclusion: Butyric acid derivatives effectively induced apoptosis in HCT116 cells.
\end{abstract}

The microorganisms present in the human colon markedly influence the biology of the host through dietary fiber fermentation in the colonic lumen. Diet plays a major role in shaping the gut microbiota throughout life span (1-3). The major dietary fiber fermentation products are short-chain fatty acids, which are responsible for the beneficial effects of gut bacteria on colonic health (4). Any imbalance in the colonic microbiota will lead to digestive diseases. One of the life threatening diseases associated with imbalanced diet and microbiota is colon cancer (5). Colon cancer is the second leading cause of cancer death and the third in terms of incidence worldwide accounting for over 1.8 million new cases each year (6). Studies have suggested that high intake of dietary fiber reduces the risk of colorectal cancer $(7,8)$. The presence of dietary fiber fermentation product, butyric acid, in the colonic lumen is linked to decreased incidence

Correspondence to: Harikumaran-Thampi, Balakrishnan-Saraswathi, Department of Life Sciences, University of Calicut, Malappuram 673635, Kerala, India. Tel: +91 4942407410, e-mail: drhari@uoc.ac.in, bsharik111@gmail.com

Key Words: Butyric acid, colon cancer, GPR109A, HCT116, cell cycle, caspase-3. of colorectal cancer via gut microbiota (9). Butyrate producing gut bacterial strains have histone deacetylase (HDAC) inhibitory action (10); the tumor-suppressive function of butyric acid is mainly due to this HDAC inhibitory action (11).

The antitumor effect of butyric acid is attributed mainly to growth inhibition and apoptosis in various cells $(12,13)$. Cell death is driven by caspases through direct stimulation of proapoptotic molecules and induction of tumor suppressor function (14). Some derivatives and prodrugs of butyric acid have been shown to induce apoptosis in a variety of tumor cells in vitro $(15,16)$. Besides the HDAC inhibitory action, butyrate also affects colon cells by acting as a ligand for GPR109A. It is a G-protein coupled receptor for nicotinate (niacin), which is silenced in colon cancer cell lines and its re-expression induces apoptosis in the presence of butyrate or nicotinate (17). The short half-life of butyric acid restricts its therapeutic application in cancer cells (18). This study examined the basic mechanisms behind the anti-cancer activity of some butyric acid derivatives in colorectal cancer cell lines.

\section{Materials and Methods}

Cell culture. Human colorectal carcinoma cell line, HCT116, was obtained from the National Centre for Cell Sciences, Pune. Cells were cultured in RPMI1640 media (Sigma-Aldrich, Darmstadt, Germany) supplemented with 10\% Fetal Bovine Serum (FBS) and antibioticantimycotic solution $(1 \mathrm{ml} / 100 \mathrm{ml})$ in a humidified atmosphere at $37^{\circ} \mathrm{C}$ with $5 \% \mathrm{CO}_{2}(19)$.

Determination of $I_{50}$ value of butyric acid derivatives in HCT116 cells. $\mathrm{IC}_{50}$ values of sodium butyrate (Himedia), indole-3-butyric acid (Fischer Scientific, Mumbai, India), tributyrin (Himedia), 2-amino-nbutyric acid (Sisco Research Laboratories Pvt. Ltd., Mumbai, India) and nicotinate (S D Fine-Chem Limited, Maharashtra, India) were determined using 3-(4,5-dimethylthiazol-2-yl)-2,5-diphenyl tetrazolium bromide (MTT) assay. Cells were treated with increasing concentrations (1-10 mM) of butyric acid derivatives, nicotinate (GPR109A receptor ligand) and 5-fluorouracil (Himedia) (Positive control) for 24,48 and $72 \mathrm{~h}(15,20)$. Stock solutions of indole-3butyric acid and tributyrin were prepared in dimethyl sulfoxide (DMSO) and that of other compounds were prepared in phosphate buffered saline (PBS). 
Morphological assessment of apoptotic cells by Acridine Orange staining. To perform morphological analysis of cell nuclei, Acridine orange staining was performed. A total of $8.825 \times 10^{5}$ HCT 116 cells were seeded in cell culture flasks. Cells were treated with $\mathrm{IC}_{50}$ concentrations of butyric acid derivatives, nicotinate and 5fluorouracil for $24 \mathrm{~h}$. After $24 \mathrm{~h}$ of treatment, cells were harvested and resuspended in PBS. Then, the cells were stained with $5 \mu \mathrm{g} / \mathrm{ml}$ acridine orange in PBS and observed under a fluorescent microscope (Leica DM6 B) (21).

Comet assay. Comet assay was performed to analyse DNA damage. HCT116 cells were treated with $\mathrm{IC}_{50}$ concentration of butyric acid derivatives as well as Nicotinate for $24 \mathrm{~h}$. A total of $100 \mu \mathrm{l}$ of $0.5 \%$ normal melting agarose in PBS was dropped onto a microslide, covered with a coverslip, and then placed at $4^{\circ} \mathrm{C}$ for $10 \mathrm{~min}$. The coverslip was removed and $50 \mu \mathrm{l}$ cell suspension was mixed with 50 $\mu \mathrm{l}$ of $1 \%$ low melting agarose and applied on top of the gel, coated over the microslide, covered with a coverslip, and placed at $4^{\circ} \mathrm{C}$ for $10 \mathrm{~min}$. The coverslip was again removed and a third coating with 50 $\mu \mathrm{l}$ of $0.5 \%$ low melting agarose was placed on the gel and allowed to set at $4^{\circ} \mathrm{C}$ for $15 \mathrm{~min}$. The coverslips were removed and the slides were immersed in an ice-cold lysis solution $(2.5 \mathrm{M} \mathrm{NaCl}, 100 \mathrm{mM}$ EDTA, $10 \mathrm{mM}$ Tris, $90 \mathrm{mM}$ sodium sarcosinate, $\mathrm{NaOH}, \mathrm{pH} 10,1 \%$ Triton X-100 and 10\% DMSO) and kept at $4^{\circ} \mathrm{C}$ for $2 \mathrm{~h}$. Then the slides were placed horizontally in an electrophoresis chamber filled with the buffer ( $300 \mathrm{mM} \mathrm{NaOH}, 1.2 \mathrm{mM}$ EDTA) and the DNA was allowed to unwind for $30 \mathrm{~min}$. Then, electrophoresis was carried out at $25 \mathrm{~V}$ and $300 \mathrm{~mA}$ for $20 \mathrm{~min}$. The slides were removed and washed in a neutralization buffer ( $400 \mathrm{mM}$ Tris, $\mathrm{HCl}, \mathrm{pH} 7.5)$. Cells were stained with $20 \mu \mathrm{l}$ of ethidium bromide $(20 \mu \mathrm{g} / \mathrm{ml})$ and the slides were scored for comets by fluorescence microscopy (Leica DM6 B) (22).

Caspase- 3 assay. Caspase- 3 activity was assessed using a colorimetric method. This assay is based on the detection of the amount of AcDEVD-p-NA substrate cleaved by cell lysates to release the colored p-NA (Para nitroanilline) molecule. HCT 116 cells (5000 cells/well) were treated with $\mathrm{IC}_{50}$ concentration of butyric acid derivatives as well as nicotinate for $24 \mathrm{~h}$. Following treatment, the cells were washed in PBS and suspended in lysis buffer (50 Mm HEPES, PH 7.4, $5 \mathrm{mM}$ Triton X-100, $5 \mathrm{mM}$ DTT) for $15 \mathrm{~min}$. Lysed cells were centrifuged at $16,000 \mathrm{rpm}$, at $4^{\circ} \mathrm{C}$ for $15 \mathrm{~min}$. Lysate protein concentrations were determined using the Bradford assay. For each assay, 10-60 $\mu \mathrm{l}$ of cell lysate were added to each tube containing 0.07 $\mathrm{mM}$ substrate in assay buffer (20 mM HEPES, PH 7.4, 0.1\% Triton X100, 5 mM DTT, 2 mM EDTA), bringing the total volume of each well to $100 \mu$ l. Caspase- 3 activity was assessed by measuring the optical density at $405 \mathrm{~nm}$ using an AM 2100 Microplate Reader (ALERE). Activity was expressed as $\mu$ mol p-NA released per min per milligram of protein (23).

Cell cycle analysis. For analysing distribution of cells in the different phases of the cell cycle, HCT 116 cells $(100000$ cells $/ \mathrm{ml})$ treated with $\mathrm{IC}_{50}$ concentration of indole-3-butyric acid and tributyrin. Camptothecin $(15 \mu \mathrm{M})$ was used as a standard control. The cells were fixed in cold $70 \%$ ethanol and stored at $4^{\circ} \mathrm{C}$. Cells were incubated in propidium iodide/RNase staining buffer and cell cycle was analysed using a BD FACS calibur (15). PI histogram of the gated cell singlets distinguished cells at the $G_{0} / G_{1}, S$, and $G_{2} / M$ cycle phases. Gating of cell cycle phases was approximate and can be refined using software (Cell Quest Software, Version 6.0) analysis.
Table I. The $I C_{50}$ values of butyric acid derivatives at 24,48 and $72 \mathrm{~h}$.

\begin{tabular}{lccc}
\hline Test compounds & \multicolumn{3}{c}{ IC $_{50}$ Values $(\mathrm{mM})$} \\
\cline { 2 - 4 } & $24 \mathrm{~h}$ & $48 \mathrm{~h}$ & $72 \mathrm{~h}$ \\
\hline Sodium butyrate & $9.53 \pm 0.55$ & $7.83 \pm 0.46$ & $5.98 \pm 0.12$ \\
Tributyrin & $4.94 \pm 0.19$ & $5.01 \pm 0.38$ & $3.30 \pm 0.22$ \\
Indole-3 butyric acid & $6.28 \pm 0.10$ & $5.84 \pm 0.16$ & $4.39 \pm 0.25$ \\
2-Amino-n- butyric acid & $8.09 \pm 0.21$ & $5.75 \pm 0.02$ & $4.65 \pm 0.10$ \\
Nicotinate & $15.13 \pm 1.34$ & $4.65 \pm 0.21$ & $3.71 \pm 0.03$ \\
5-Fluorouracil & $1.98 \pm 0.23$ & $1.12 \pm 0.19$ & $0.99 \pm 0.42$ \\
\hline
\end{tabular}

Statistical analysis. Data are presented as mean \pm standard deviation. One-way analysis of Variance (ANOVA) with Duncan's post-hoc test using SPSS 21 software, were used to assess the level of significance between means at $95 \%$ confidence interval $(p<0.05)$.

\section{Results}

Determination of $I_{50}$ value of butyric acid derivatives. Cell viability assay was performed to evaluate the $\mathrm{IC}_{50}$ of butyric acid derivatives as well as nicotinate in HCT116 cells. Among the butyric acid derivatives, indole-3-butyric acid and tributyrin showed the lowest $\mathrm{IC}_{50}$ values at $24 \mathrm{~h}$ of incubation $(6.28 \pm 0.10,4.94 \pm 0.19 \mathrm{mM}$ respectively). There was no significant difference between the $\mathrm{IC}_{50}$ values of indole-3butyric acid and tributyrin at 48 and $72 \mathrm{~h}$ of incubation. The $\mathrm{IC}_{50}$ values of butyric acid derivatives as well as Nicotinate are shown in Table I.

Morphological assessment of apoptotic cells by Acridine Orange staining. Fluorescent microscopy was performed after staining cells treated with Butyric acid derivatives as well as nicotinate with acridine orange. The fluorescent images revealed that these compounds induced apoptosis of HCT116 cells (Figure 1). The detached population of cells treated with butyric acid derivatives showed the typical morphological characteristics of apoptosis such as condensed chromatin and fragmented nuclei compared with the untreated control cells.

Analysis of DNA damage by the comet assay. The DNA damage induced following treatment of cells with butyric acid derivatives was analysed using single-cell gel electrophoresis (comet assay) in agarose gel matrix. No comet like appearance was observed in untreated cells. After treatment of HCT116 cells with the $\mathrm{IC}_{50}$ concentration of butyric acid derivatives as well as nicotinate for $24 \mathrm{~h}$, well-formed comets were observed (Figure 2).

Caspase- 3 assay. Treatment of HCT116 cells with butyric acid derivatives, as well as nicotinate significantly induced caspase3 activity compared with the untreated control cells (Figure 


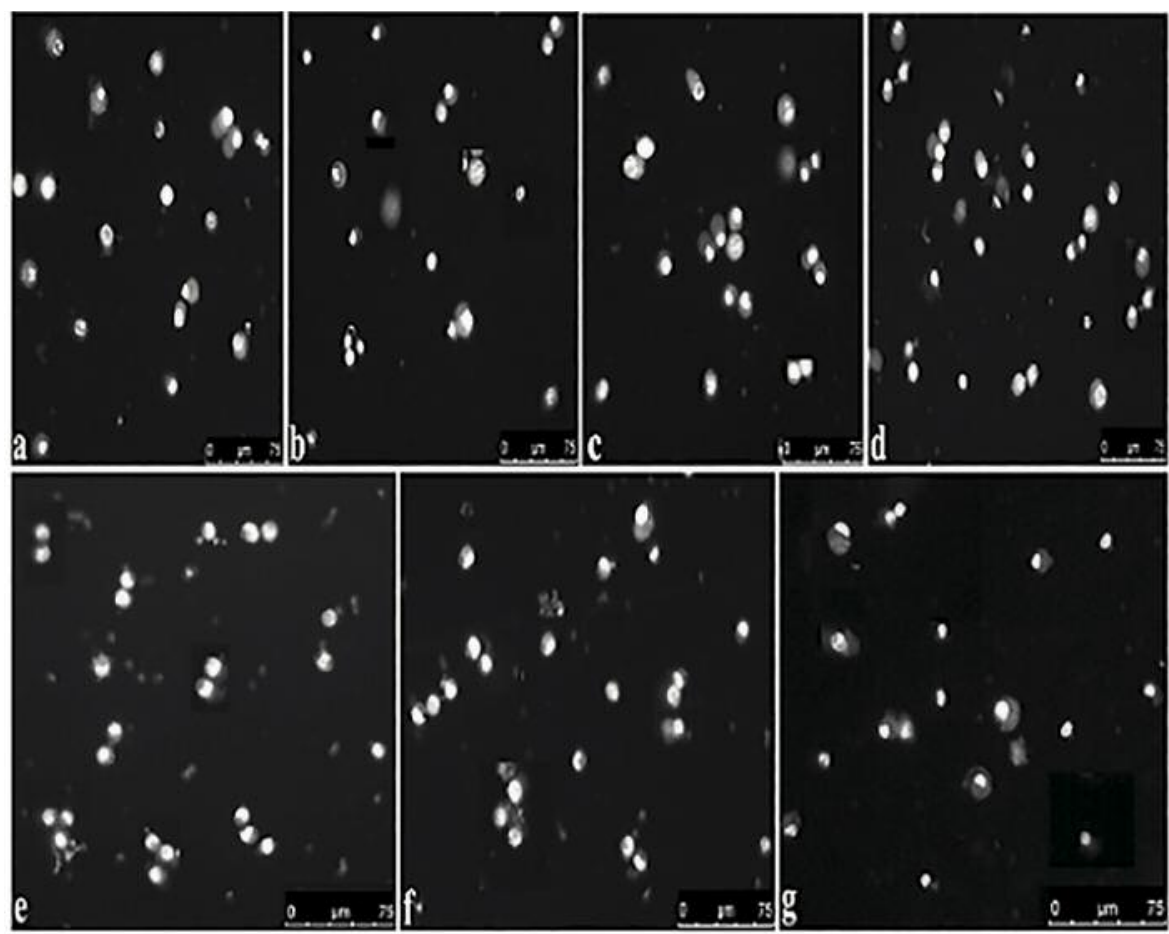

Figure 1 . HCT 116 cells stained with acridine orange after treatment with $I C_{50}$ values of a) sodium butyrate, $b$ ) indole-3-butyric acid, c) tributyrin, d) 2-amino-n-butyric acid e) nicotinate, f) 5-fluorouracil, and g) untreated control.

3). There was no significant difference between the caspase-3 activity in cells treated with butyric acid derivatives, nicotinate and 5-fluorouracil.

Effect of indole-3-butyric acid and tributyrin on the cell-cycle distribution of HCT116 cells. To analyse the mechanism of the the suppressive effect of indole-3-butyric acid and tributyrin on HCT116 cells, the changes in the cell cycle distribution were monitored by flow cytometry. The DNA content histogram is shown in Figure 4. Compared to the untreated control cells, $58.14 \pm 0.16 \%$ and $51.15 \pm 1.02 \%$ of HCT116 cells treated with indole-3-butyric acid and tributyrin arrested at the $\mathrm{G}_{0} / \mathrm{G}_{1}$ phase, respectively. Also, 20.91 $\pm 0.86 \%$ and $17.07 \pm 0.06 \%$ of HCT116 cells treated with indole-3-butyric acid and tributyrin, respectively, arrested at the $\mathrm{G}_{2} / \mathrm{M}$ phase compared to cells treated with camptothecin.

\section{Discussion}

In this study, we investigated the mechanisms through which butyric acid derivatives trigger apoptosis in HCT116 cells. The anti-proliferative and apoptotic activity of butyric acid, is mainly due to their histone hyperacetylation (24). Besides the butyric acid derivatives, the effect of nicotinate on HCT116 cells was also tested, because it acts as a ligand for GPR109A receptor protein. Studies have shown that the receptor is highly expressed in normal human colon tissue, but is silenced in colon carcinoma cells (25). Nicotinate and butyrate, suppress colon cancer cells in a GPR109A-dependent manner (26). Compared with other derivatives, the $\mathrm{IC}_{50}$ value of nicotinate was highest at $24 \mathrm{~h}$. This result suggests that, as ligands, butyric acid derivatives are more cytotoxic in cancer cells than nicotinate. An earlier study has demonstrated induction of cytotoxicity by tributyrin emulsion in melanoma, with an $\mathrm{IC}_{50}$ of $\sim 2 \mathrm{mM}$ (27).

To investigate the involvement of apoptosis in butyric acid treated cells, morphological analysis using acridine orange staining was performed. The cellular changes of apoptosis include, cell shrinkage, masses of condensed chromatin and membrane blebbing (28). Cells treated with $\mathrm{IC}_{50}$ concentration of butyric acid derivatives as well as nicotinate showed early apoptosis features including membrane blebbing and chromatin condensation and these morphological features of apoptosis were comparable with those of cells treated with 5Fluorouracil, the positive control. DNA damage is another hallmark of apoptosis. Well-formed comets were observed in the cells treated with indole-3-butyric acid, tributyrin and nicotinate. No comet like structures were found in the untreated control.

It was observed that apoptosis occurred in HCT116 cells treated with butyric acid derivatives via caspase-3 mediated signalling. The activity of caspase- 3 in cells treated with 

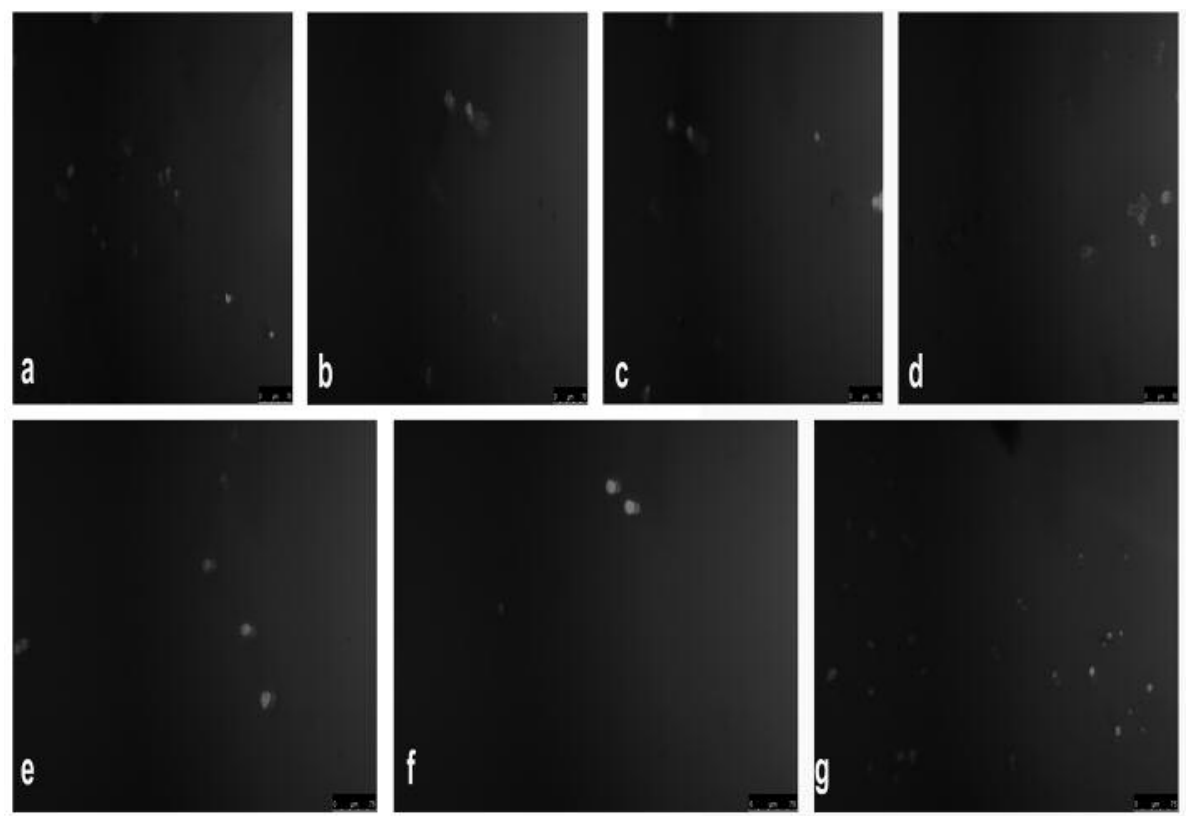

Figure 2. Comet assay of HCT 116 cells treated with $I_{50}$ concentrations of a) sodium butyrate, $b$ ) indole-3-butyric acid, c) tributyrin, d) 2-aminon-butyric acid, e) 5-fluorouracil and f) untreated control.

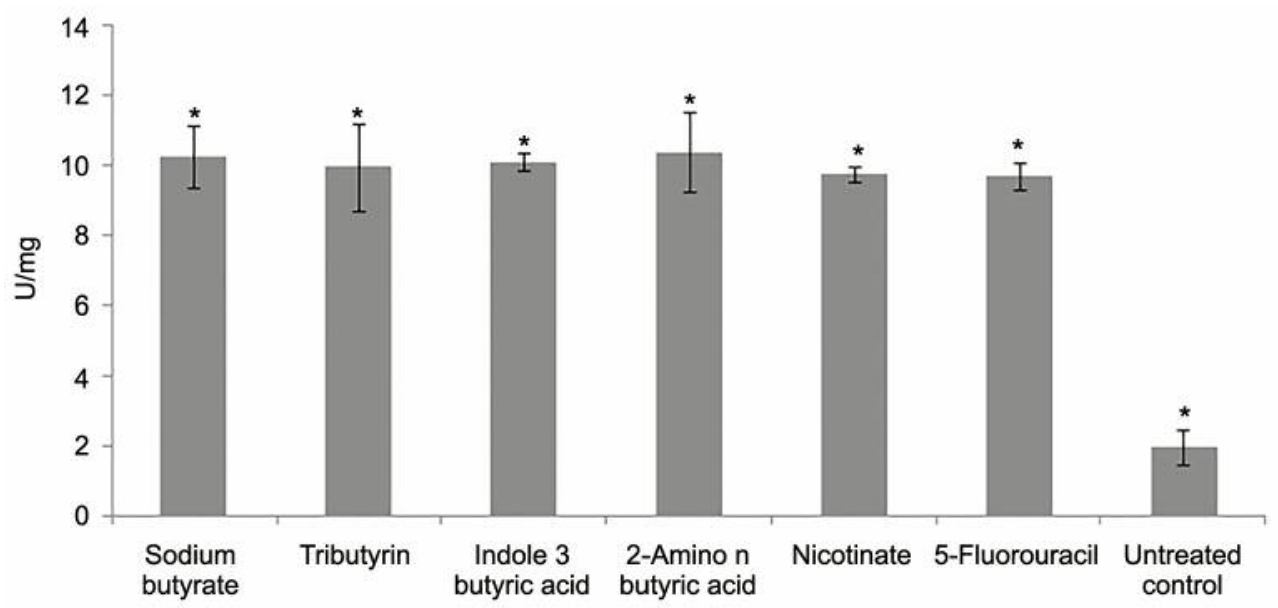

Figure 3. Activity of caspase-3 in HCT 116 cells after treating with $I_{50}$ concentration of butyric acid derivatives, nicotinate and 5-fluorouracil at $24 \mathrm{~h}$. Data are presented as mean \pm standard deviation in 6 wells per experiment from 3 independent experiments. ${ }^{*} p<0.05$ considered statistically significant.

sodium butyrate, indole-3-butyric acid, tributyrin, 2-amino-nbutyric acid, nicotinate and 5-fluorrouracil, in $\mathrm{U} / \mathrm{mg}$ of protein, were $10.28 \pm 0.9,10.13 \pm 0.23,9.98 \pm 1.25,10.4 \pm 1.13,9.76 \pm 0.22$ and $9.71 \pm 0.4$ respectively. The untreated control showed an activity of $1.98 \pm 0.49 \mathrm{U} / \mathrm{mg}$ of protein. Caspase- 3 is a frequently activated protease in mammalian cell apoptosis (29). Its activation in colon cancer cells depends on peroxisome proliferator-activated receptor (30). Previous studies have suggested that butyrate induces apoptosis by caspase-3 activation in various kinds of colon cancer cell lines and is mediated via induction of caspase- 3 mediated cleavage of poly ADP ribose polymerase (PARP) $(31,32)$.

Cell cycle analysis was performed to determine the effect of butyric acid derivatives on cell cycle progression of HCT116 cells. The derivatives, indole-3-butyric acid and tributyrin showed the least $\mathrm{IC}_{50}$ value at $24 \mathrm{~h}$ of incubation. So, cell cycle distribution following treatment with these two derivatives was analysed by flow cytometry. The results 

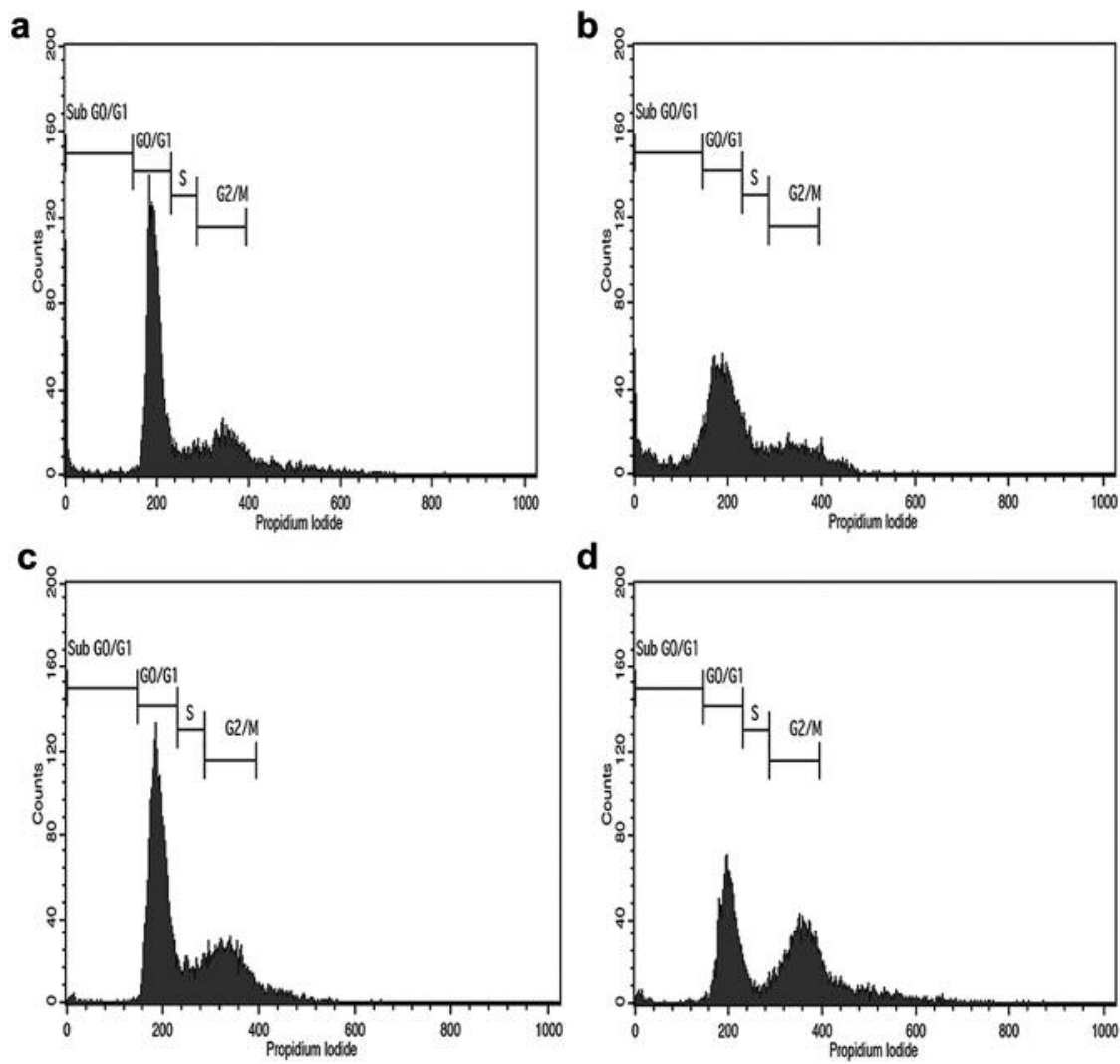

Figure 4. DNA histogram of HCT116 cells treated with $I_{50}$ concentration of a) Indole-3-butyric acid, b) Tributyrin, c) Untreated control, d) Standard drug camptothecin.

suggested that a higher number of cells were arrested at $\mathrm{G}_{0} \mathrm{G}_{1}$ phase. A previous study has shown that butyrate causes $\mathrm{G}_{1}$ arrest in cancer cell lines (33). Several studies have shown the cytotoxic effect of butyric acid in different cancer cells $(12,34)$ and it has been suggested that it induces apoptosis in colon cancer cells $(35,36)$. Our results clearly show that butyric acid derivatives are the most effective inducers of apoptosis in HCT116 cells.

\section{Conclusion}

The present study showed that butyric acid derivatives as well as nicotinate mediate caspase- 3 dependent apoptotic pathway in HCT116 cells. The growth inhibitory effects are associated with alterations in cell cycle. Thus the present study suggested that butyric acid derivatives could be used to develop therapeutic interventions of colon cancer treatment.

\section{Conflicts of Interest}

The Authors have no conflicts of interest to declare regarding this study.

\section{Authors' Contributions}

LP contributed to the experimental work; all Authors participated in data analysis; HTBS coordinated the study. All Authors gave final approval for publication.

\section{Acknowledgements}

The Authors thank the Department of Science and Technology (DST), New Delhi, India for rendering financial support for the work and the award of research fellowship with Reg No: IF130652.

\section{References}

1 Jandhyala SM, Talukdar R, Subramanyam C, Vuyyuru H, Sasikala M and Reddy DN: Role of the normal gut microbiota. World J Gastroenterol 21: 8836-8847, 2015. PMID: 26269668. DOI: $10.3748 /$ wjg.v21.i29.8787

2 Bäckhed F, Ley RE, Sonnenburg JL, Peterson DA and Gordon JI: Host-bacterial mutualism in the human intestine. Science 307: 19151920, 2005. PMID: 15790844. DOI: 10.1126/ science.1104816

3 Thursby E and Juge N: Introduction to the human gut microbiota. Biochem J 474: 1823-1836, 2017. PMID: 28512250. DOI: 10.1042/BCJ20160510 
4 Ríos-Covián D, Ruas-Madiedo P, Margolles A, Gueimonde M, De los Reyes-Gavilán CG and Salazar N: Intestinal short chain fatty acids and their link with diet and human health. Front Microbiol 7: 185, 2016. PMID: 26925050. DOI: 10.3389/fmicb. 2016.00185

5 Jahani-Sherafat S, Alebouyeh M, Moghim S, Amoli HA and Ghasemian-Safaei H: Gastroenterology and hepatology from bed to bench. Role of gut microbiota in the pathogenesis of colorectal cancer; a review article. Gastroenterol Hepatol Bed Bench 11: 101-109, 2018. PMID: 29910850.

6 Bray F, Ferlay J, Soerjomataram I, Siegel RL, Torre LA and Jemal A: Global cancer statistics 2018: GLOBOCAN estimates of incidence and mortality worldwide for 36 cancers in 185 countries. CA: Cancer J Clin 68: 394-424, 2018. PMID: 30207593. DOI: $10.3322 /$ caac.21492

7 Kunzmann AT, Coleman HG, Huang WY, Kitahara CM, Cantwell MM and Berndt SI: Dietary fiber intake and risk of colorectal cancer and incident and recurrent adenoma in the prostate, lung, colorectal, and ovarian cancer screening trial. Am J Clin Nutr 102: 881-890, 2015. PMID: 26269366. DOI: 10.3945/ajcn. 115.113282

8 Clausen MR, Bonnén H and Mortensen PB: Colonic fermentation of dietary fibre to short chain fatty acids in patients with adenomatous polyps and colonic cancer. Gut 32: 923-928, 1991. PMID: 1653178. DOI: 10.1136/gut.32.8.923

9 Bishehsari F, A. Engen P, Z. Preite N, E. Tuncil Y, Naqib A, Shaikh M, Rossi M, Wilber S, Green SJ, Hamaker BR, Khazaie K, Voigt RM, Forsyth CB and Keshavarzian A: Dietary fiber treatment corrects the composition of gut microbiota, promotes SCFA production, and suppresses colon carcinogenesis. Genes 9, 2018. PMID: 29462896. DOI: $10.3390 /$ genes 9020102

10 Yuille S, Reichardt N, Panda S, Dunbar H and Mulder IE: Human gut bacteria as potent class I histone deacetylase inhibitors in vitro through production of butyric acid and valeric acid. PLoS One 13: 1-12, 2018. PMID: 30052654. DOI: 10.1371/journal.pone.0201073

11 Entin-Meer M, Rephaeli A, Yang X, Nudelman A, VandenBerg SR and Haas-Kogan DA: Butyric acid prodrugs are histone deacetylase inhibitors that show antineoplastic activity and radiosensitizing capacity in the treatment of malignant gliomas. Mol Cancer Ther 4: 1952-1961, 2006. PMID: 16373710. DOI: 10.1158/1535-7163.mct-05-0087

12 Zhang Y, Zhou L, Bao YL, Wu Y, Yu CL, Huang YX, Sun Y, Zheng LH and Li YX: Butyrate induces cell apoptosis through activation of JNK MAP kinase pathway in human colon cancer RKO cells. Chem Biol Interact 185: 174-181, 2010. PMID: 20346929. DOI: 10.1016/j.cbi.2010.03.035

13 Blouin JM, Penot G, Collinet M, Nacfer M, Forest C, LaurentPuig P, Coumoul X, Barouki R, Benelli C and Bortoli S: Butyrate elicits a metabolic switch in human colon cancer cells by targeting the pyruvate dehydrogenase complex. Int J Cancer 128 : 2591-2601, 2011. PMID: 20715114. DOI: 10.1002/ijc. 25599

14 Galluzzi L, López-Soto A, Kumar S and Kroemer G: Caspases connect cell-death signaling to organismal homeostasis. Immunity 44: 221-231, 2016. PMID: 26885855. DOI: 10.1016/ j.immuni.2016.01.020

15 Li LZ, Deng HX, Lou WZ, Sun XY, Song MW, Tao J, Xiao BX and Guo JM: Growth inhibitory effect of 4-phenyl butyric acid on human gastric cancer cells is associated with cell cycle arrest. World J Gastroenterol 18: 79-83, 2012. PMID: 22228974. DOI: 10.3748/wjg.v18.i1.79
16 Gaschott T, Steinhilber D, Milovic V and Stein J: Tributyrin, a stable and rapidly absorbed prodrug of butyric acid, enhances antiproliferative effects of dihydroxycholecalciferol in human colon cancer cells. J Nutr 131: 1839-1843, 2001. PMID: 11385076. DOI: $10.1093 / \mathrm{jn} / 131.6 .1839$

17 Thangaraju M, Cresci GA, Liu K, Ananth S, Gnanaprakasam JP, Browning DD, Mellinger JD, Smith SB, Digby GJ, Lambert NA, Prasad PD and Ganapathy V: GPR109A is a G-protein-coupled receptor for the bacterial fermentation product butyrate and functions as a tumor suppressor in colon. Cancer Res 69: 28262832, 2009. PMID: 19276343. DOI: 10.1158/0008-5472.CAN08-4466

18 Daniel P, Brazier M, Cerutti I, Pieri F, Tardivel I, Desmet G, Baillet $\mathrm{J}$ and Chany $\mathrm{C}$ : Pharmacokinetic study of butyric acid administered in vivo as sodium and arginine butyrate salts. Clin Chim Acta 181: 255-263, 1989. PMID: 2667816. DOI: 10.1016/ 0009-8981(89)90231-3

19 Langdon SP: Cancer cell culture - Methods and protocols. In: Methods in Molecular Medicine 348, 2011. PMID: 21516394. DOI: 10.1007/978-1-61779-080-5_2

$20 \mathrm{Mu} \mathrm{D}$, Gao Z, Guo H, Zhou G and Sun B: Sodium butyrate induces growth inhibition and apoptosis in human prostate cancer DU145 cells by up-regulation of the expression of annexin A1. PLoS One 8: 2-9, 2013. PMID: 24086397. DOI: 10.1371/journal. pone.0074922

21 Orchel A, Dzierzewicz Z, Parfiniewicz B, Weǵlarz L and Wilczok T: Butyrate-induced differentiation of colon cancer cells is PKC and JNK dependent. Dig Dis Sci 50: 490-498, 2005. PMID: 15810631. DOI: $10.1007 / \mathrm{s} 10620-005-2463-6$

22 Nandhakumar S, Parasuraman S, Shanmugam M, Rao Kr, Chand $\mathrm{P}$ and Bhat Bv: Evaluation of DNA damage using single-cell gel electrophoresis (Comet Assay). J Pharmacol Pharmacother 2: 107, 2011. PMID: 21772771. DOI: 10.4103/0976-500X.81903

23 Medina V, Edmonds B, Young GP, James R, Appleton S and Zalewski PD: Induction of caspase-3 protease activity and apoptosis by butyrate and trichostatin a (Inhibitors of histone deacetylase): Dependence on protein synthesis and synergy with a mitochondrial/cytochrome c-dependent pathway. Cancer Res 57: 3697-3707, 1997. PMID: 9288776.

24 Hinnebusch BF, Meng S, Wu JT, Archer SY and Hodin RA: The effects of short-chain fatty acids on human colon cancer cell phenotype are associated with histone hyperacetylation. J Nutr 132: 1012-1017, 2018. DOI: 10.1093/jn/132.5.1012

25 Bardhan K, Paschall A V, Yang D, Chen MR, Simon PS, Yangzom B, Martin PM, Thangaraju M, Browning DD, Ganapathy V, Heaton $\mathrm{CM}, \mathrm{Gu} \mathrm{K}$, Lee JR and Liu K: IFNy induces DNA methylationsilenced GPR109A expression via pSTAT1/p300 and H3K18 acetylation in colon cancer. Cancer Immunol Res 3: 795-805, 2015. PMID: 28299348. DOI: 10.1158/2326-6066.CIR-14-0164

26 Singh N, Gurav A, Sivaprakasam S, Brady E, Padia R, Shi H, Thangaraju M, Prasad PD, Manicassamy S, Munn DH, Lee JR, Offermanns S and Ganapathy V: Activation of Gpr109a, receptor for niacin and the commensal metabolite butyrate, suppresses colonic inflammation and carcinogenesis. Immunity 40: 128-139, 2014. PMID: 24412617. PMID: 24412617. DOI: 10.1016/ j.immuni.2013.12.007

27 Kang SN, Lee E, Lee MK and Lim SJ: Preparation and evaluation of tributyrin emulsion as a potent anti-cancer agent against melanoma. Drug Delivery 18: 143-149, 2011. PMID: 20946006. DOI: $10.3109 / 10717544.2010 .522610$ 
28 Baskić D, Popović S, Ristić P and Arsenijević NN: Analysis of cycloheximide-induced apoptosis in human leukocytes: Fluorescence microscopy using annexin V/propidium iodide versus acridin orange/ethidium bromide. Cell Biol Int 30: 924932, 2006. PMID: 16895761. DOI: 10.1016/j.cellbi.2006.06.016

29 Porter AG and Jänicke RU: Emerging roles of caspase-3 in apoptosis. Cell Death Differ 6: 99-104, 1999. PMID: 10200555. DOI: $10.1038 /$ sj.cdd.4400476

30 Schwab M, Reynders V, Ulrich S, Zahn N, Stein J and Schröder $\mathrm{O}:$ PPAR $\gamma$ is a key target of butyrate-induced caspase- 3 activation in the colorectal cancer cell line Caco-2. Apoptosis 11: 1801-1811, 2006. PMID: 16927016. DOI: 10.1007/s10495-006-9788-2

31 Avivi-green C, Polak-charcon S, Madar Z and Schwartz B: Different molecular events account for butyrate-induced apoptosis in two human colon cancer cell lines. J Nutr 132(7): 1812-1818, 2002. PMID: 12097652. DOI: 10.1093/jn/132.7. 1812

32 Ruemmele FM, Dionne S, Qureshi I, Sarma DS, Levy E and Seidman EG: Butyrate mediates Caco-2 cell apoptosis via upregulation of pro-apoptotic $\mathrm{BAK}$ and inducing caspase-3 mediated cleavage of poly-(ADP-ribose) polymerase (PARP). Cell Death Differ 6: 729-735, 1999. PMID: 10467346. DOI: 10.1038/sj.cdd.4400545

33 Nakano K, Mizuno T, Sowa Y, Orita T, Yoshino T, Okuyama Y, Fujita T, Ohtani-Fujita N, Matsukawa Y, Tokino T, Yamagishi H, Oka T, Nomura H and Sakai T: Butyrate activates the WAF1/ Cip1 gene promoter through $\mathrm{Sp} 1$ sites in a p53-negative human colon cancer cell line. J Biol Chem 272: 22199-22206, 1997. PMID: 9268365. DOI: 10.1074/jbc.272.35.22199
34 Singh NP and Lai HC: Synergistic cytotoxicity of artemisinin and sodium butyrate on human cancer cells. Anticancer Res 25: 43254331, 2005. PMID: 16309236.

35 Mandal M, Olson DJ, Sharma T, Vadlamudi RK and Kumar R: Butyric acid induces apoptosis by up-regulating Bax expression via stimulation of the c-Jun N-terminal kinase/activation protein1 pathway in human colon cancer cells. Gastroenterology 120 : 71-78, 2001. PMID: 11208715. DOI: 10.1053/gast.2001.20897

36 Kapuvári B, Hegedüs R, Schulcz Á, Manea M, Tóvári J, Gacs A, Vincze B and Mező G: Improved in vivo antitumor effect of a daunorubicin - GnRH-III bioconjugate modified by apoptosis inducing agent butyric acid on colorectal carcinoma bearing mice. Invest New Drugs 34: 416-423, 2016. PMID: 27146514. DOI: $10.1007 / \mathrm{s} 10637-016-0354-7$

Received April 27, 2019

Revised June 5, 2019

Accepted June 6, 2019 